\title{
Introduction into France of the Japanese oyster (Crassostrea gigas)
}

\author{
Henri Grizel and Maurice Héral
}

\begin{abstract}
Grizel, H., and Héral, M. 1991. Introduction into France of the Japanese oyster (Crassostrea gigas). - J. Cons. int. Explor. Mer, 47: 399-403.

The Japanese oyster (Crassostrea gigas) has been introduced in France on a large scale to replace cultivation of the Portuguese oyster (Crassostrea angulata), affected by a viral disease. The importation took place from 1971 to 1975 , with broodstock coming from British Columbia (Canada) and spat from Japan. Good growth rate and success of the natural setting on the French Atlantic coast attested to the success of this implantation, with a production which reached $80000 \mathrm{t}$ by 1976 . The precautionary measures associated with this transfer limited the implantation of an introduced fauna, 15 years after, to: Balanus amphitrite, Aiptasia pulchella and, on the Mediterranean coast, Undaria pinnatifida and Laminaria japonica. The authors also discuss the possible role of Crassostrea gigas in spreading the viral disease.
\end{abstract}

L'huître japonaise (Crassostrea gigas) a été introduite massivement en France dans le but de subvenir au remplacement de l'élevage de l'huître portugaise (Crassostrea angulata) décimée par une maladie virale. Ces importations effectuées de 1971 à 1975 concernent des géniteurs provenant de Colombie Britannique (Canada) et du naissain en provenance du Japon. De bonnes performances de croissance et le succès du captage sur la côte atlantique française traduisent la réussite de l'implantation de cette espèce dont la production a atteint, dès 1976, 80000 tonnes. Les précautions associées à cette importation ont permis de limiter l'implantation d'une faune associée dont les principales espèces, 15 ans après, sont: Balanus amphitrite, Aiptasia pulchella et, sur la côte méditerranéenne, Undaria pinnatifida et Laminaria japonica. Enfin est discuté le rôle possible de Crassostrea gigas dans la propagation de la maladie à virus.

Henri Grizel: IFREMER, Laboratoire de Pathologie et de Génétique des Invertébrés Marine (L.P.G.I.M.) BP 133, 17390 La Tremblade (France). Maurice Héral: IFREMER, Laboratoire Ecosystèmes Conchylicoles (LEC), BP 133, 17390 La Tremblade (France).

\section{Introduction}

During 1967, Portuguese oysters (Crassostrea angulata), cultivated mainly in the Bays of Arcachon and Marennes-Oléron but also in different rivers of the Brittany coast, were affected by a disease characterized by lesions of the labial gills (Comps, 1969, 1970a). From 1970 to 1972 the oysters of this species developed a second syndrome, the main signs of which were invasion of connective tissues by blood cells, some showing an abnormal size with inclusions, and an increase in the number of brown cells (Comps, 1970a; Deltreil, 1973). These symptoms occurred simultaneously with a major mortality of the oysters ( $C$. angulata), which nearly disappeared from the French coast between 1970 and 1973. Further studies allowed Comps et al. (1976) and Comps (1983) to demonstrate the infectious nature of this epizootic caused by an iridovirus. No studies have been reported on the economic effects of the disease on oyster culture, but the annual loss in total weight of adult oysters reached $60000 \mathrm{t}$ and the loss in production was estimated at 556 million francs. Faced with this crisis, which affected nearly 5000 oystermen, it was necessary quickly to find a solution with a substitute species, principally to maintain employment. After extensive observations and discussions, the massive introduction to France of the cupped oyster, Crassostrea gigas, was officially decided upon and carried out, beginning in 1970.

\section{Historical}

The unofficial nature of some of the first importations does not allow us to trace exactly the early history of the introduction of $C$. gigas. However, the first spat 
from Japan were probably planted in the Bay of Marennes-Oléron in 1966 (Le Borgne et al., 1973) and Trochon, pers. comm.). These transfers were made by an oysterman fascinated by the fast growth rate and the quality of $C$. gigas at a time when the production of $C$. angulata was declining, the stocks were exhibiting higher levels of mortality, and large decreases in growth rates were occurring (Héral et al., 1986). The first test gave good results, so the oystermen decided to introduce other samples of Japanese spat from Sendai Prefecture.

Faced with the increase in introductions, and because of a concomitant increase in mortality of $C$. angulata with the introduction of $C$. gigas, the "Institut Scientifique et Technique des Pêches Maritimes" proposed that the importation be stopped. This measure was disapproved of by some of the oystermen. The action brought about a visit to Japan by French experts in 1969 with the aim of surveying the different oyster producing areas to determine the quality of the Japanese oyster and the spat, to examine the fouling organisms, and to study the pathology of this species, especially the lesions of the labial gills which had been observed. After comparing the malformations of the labial gills of the two species concerned, the mission concluded that the lesions discovered on $C$. gigas gills were due to mechanical causes. The mass mortalities in C. angulata cultivation during 1970 and 1971, at a time when the imported C. gigas appeared healthy (Comps, 1972), led to the official decision to introduce this exotic species to the French coast.

\section{Importation operations}

Two operations were carried out: one to create sanctuaries, the other to supply the oystermen with spat.

\section{"Operation Resur"}

The operation called "Resur" was accomplished after a visit by experts to British Columbia (Canada); they confirmed the technical feasibility of transferring large quantities of adult oysters for reproduction and investigated the sanitary quality of the Canadian oyster beds.
The Canadian oysters ( $C$. gigas) were directly planted from 1971 to 1975 in different French bays, where the cultivation occurred. Histological observations during all these operations showed that they were free of disease. The quantities of oysters planted in the different bays and years are given in Table 1 .

\section{Importation of spat for cultivation}

From 1971 to 1977 spat were imported from Japan to reseed the oyster grounds. The imported spat were cultchless or were set on oyster shells or scallop shells. Each imported sample had certificates of origin and sanitation. Control of the samples was carried out when the truck arrived for customs clearance. Control measures included an index of quality for the spat, an estimate on a subsample basis of the quantities of spat, scrutiny for the presence of predators, and collection of tissues for histological analyses. Depending on the results of these examinations the whole sample could, if necessary, be destroyed. Otherwise, before being planted in French coastal areas, each shipment of spat on collectors was immersed in fresh water to destioy fouling organisms and predators, especially flatworms of the genus Pseudostylochus. Table 2 summarizes the quantities of spat which were introduced from 1971 to 1977 from Japan to the French coast.

The tests and inspections carried out on both the Canadian adult oysters and the Japanese spat not only provided data on the efficiency of the importations, but also indicated certain modifications which occurred in the biotopes.

\section{Biological data}

The massive introduction of $C$. gigas happened at a time when mass mortalities of $C$. angulata were taking place, so competition between the two species, mainly for food and space, did not occur. Since the stocks of cultivated oysters were very low after 1970 , the growth rates in length and weight were excellent in all the bays; market size was reached 18 to 20 months after setting at a mean total weight of $70 \mathrm{~g}$. This growth performance was not

Table 1. Quantities (in t) of adult oysters imported from British Columbia and planted in the main French cupped oyster bays.

\begin{tabular}{lcccccc}
\hline $\begin{array}{l}\text { Centres of } \\
\text { oyster culture }\end{array}$ & 1971 & 1972 & 1973 & 1974 & 1975 & $\begin{array}{c}\text { Total } \\
\text { (t) }\end{array}$ \\
\hline Bay of Bourgneuf & & 10 & 10 & & & 20 \\
Area of La Rochelle & & 30.5 & 58 & & 35.5 \\
Bay of Marennes-Oléron & 65 & 106 & 50 & 0 & 35 & 256 \\
Estuary of the Gironde & 52.5 & 60 & 30 & & 60 & 137.5 \\
Bay of Arcachon & 117.5 & 236.5 & 173 & 0 & 35 & 562 \\
\hline Total $(t)$ & & & & \\
\hline
\end{tabular}


Table 2. Quantities (in $\mathrm{t}$ ) of spat collectors imported from Japan and estimation of the quantity of spat.

\begin{tabular}{|c|c|c|c|c|c|c|c|}
\hline Regions & $1971 / 1972$ & $1972 / 1973$ & $1973 / 1974$ & $1974 / 1975$ & $1975 / 1976$ & $1976 / 1977$ & Total \\
\hline Mediterranean & 147 & 224 & 55 & 107 & 23.5 & 0 & 556.5 \\
\hline Arcachon & 475 & 598 & 30 & 73 & 0 & 0 & 1176 \\
\hline Marennes-Oléron & 1212 & 2536 & 210 & 546 & 0 & 10 & 4574 \\
\hline $\begin{array}{l}\text { La Rochelle and } \\
\text { Vendée }\end{array}$ & 205 & 727 & 302 & 631 & 44 & 0 & 1909 \\
\hline $\begin{array}{l}\text { Bretagne North } \\
\text { and South }\end{array}$ & 413 & 741 & 132 & 573 & 0.5 & 0 & 1859.5 \\
\hline \multirow[t]{3}{*}{ Total } & 2452 & 4826 & 729 & 1930 & 68 & 10 & 10015 \\
\hline & \multicolumn{7}{|c|}{ Estimation of quantity of spat in millions } \\
\hline & 1226 & 2413 & 365 & 965 & 34 & 5 & $\begin{array}{l}\text { More than } \\
5 \text { billion }\end{array}$ \\
\hline
\end{tabular}

sustained; the same market size required 36 to 40 months immediately after 1976 for oysters cultivated in the Bay of Marennes-Oléron, with production varying from $10000 \mathrm{t}$ to $80000 \mathrm{t}$ (Héral et al., 1986). These data were confirmed in another area by Deltreil (pers. comm.) who recorded the growth rate of experimental samples in the Bay of Arcachon. During this period (1972-1976), there was a decrease of 50\% in the annual growth rate of oysters cultivated with a starting weight of $20-25 \mathrm{~g}$ (Table 3 ).

Rebuilding of the sanctuaries resulted in natural setting on the Southwest Atlantic coast from La Rochelle to Arcachon, particularly in the Bay of MarennesOléron, in the Gironde estuary, and in the Bay of Arcachon. Since $C$. gigas larvae need a higher temperature than C. angulata larvae (Héral et al., 1986) the setting was irregular at first (Le Borgne et al., 1973), depending on summer climatic conditions. However, with the large increase in the cultivated stocks which participated in spawning, an adequate supply of $C$. gigas spat was achieved by the French oyster centres beginning in 1975 .

C. gigas has not been affected by major parasites since its introduction in France. Comps (1972) noted its resistance to gill disease of $C$. angulata. Cahour (1979) observed some young stages of Marteilia sp. in the

Table 3. Changes in the growth rate of C. gigas between 1972 and 1976 in the Bay of Arcachon, and mean weight after one year.

\begin{tabular}{lcc}
$\begin{array}{l}\text { Date of the } \\
\text { beginning of } \\
\text { the study }\end{array}$ & $\begin{array}{c}\text { Mean increase in } \\
\text { the total weight } \\
\text { after one year }\end{array}$ & $\begin{array}{c}\text { Growth rate in } \\
\text { measured from } \\
\text { starting weight } \\
\text { a year before }\end{array}$ \\
\hline 1972 & 46 & 223 \\
1973 & 44 & 203 \\
1974 & 38 & 172 \\
1975 & 33 & 151 \\
1976 & 28 & 113 \\
\hline
\end{tabular}

stomach epithelium. Summer mortalities comparable to those described in the United States by Beattie et al. (1980) have been observed several times when the sea temperature was above $21^{\circ} \mathrm{C}$, particularly in the Bay of Arcachon (Maurer et al., 1986). His (1977) reported the parasitic copepod Mytilicola orientalis associated with C. gigas, but it did not invade indigenous species.

Fauna and flora introduced in different French coastal areas and associated mainly with the spat collectors have been described by several authors. During a study in the Bourgneuf Bay, Gruet et al. (1976) identified several animal species which survived after their introduction with Japanese collectors. The main species were the annelid Hydroides enzoensi, the cnidarian Aiptasia pulchella, the mollusc Anomia chinensis, and the cirripedes Balanus amphitrite and Balanus albicostatus. Perez et al. (1984) indicated that some algae in the Thau lagoon on the Mediterranean coast were probably associated with the introduction of $C$. gigas especially Laminaria japonica and Undaria pinnatifida. However, the history of the introduction of Sargassum muticum on the North European coasts indicated that the appearance of this algae was not associated with the introduction of $C$. gigas. Indeed, Farnham et al. (1973) reported this alga for the first time in Europe in the Isle of Wight near the large harbours of Southampton and Portsmouth. Later, Gruet (1976) and Kopp (1976) reported that Sargassum muticum had crossed the channel to Normandy. However, the rapid spread on the French coast could have been promoted by the transport of oysters from one bay to another. Thus, since 1982, this alga has spread to the Southwest Atlantic coast (Gruet, 1976; Belcher et Pomellec, 1988).

\section{Technical and economic data}

The $C$. gigas introduction was accompanied by the development of new techniques, particularly setting on new collectors and culture in racks or bags on tables. This last development opened up new areas for oyster 
Table 4. Changes in the French production in $t$ of the cupped oyster for the period 1960-1975. ----- transition years between $C$. angulata and C. gigas. (Source of data: Secrétariat général de la Marine Marchande).

\begin{tabular}{lcccccc}
\hline Year & 1960 & 1970 & 1971 & 1972 & 1973 & 1975 \\
\hline Cupped oysters $(\mathrm{t})$ & 65900 & 40300 & 18800 & 53900 & 61100 & 85000 \\
\hline
\end{tabular}

production and increased the surface which could be used for oyster culture. Furthermore, the successful $C$. gigas introduction avoided a severe economic crisis in the oyster industry. Indeed, after a rapid decrease in annual production in 1971, the normal production of $C$. angulata, which had been about $65000 \mathrm{t}$ in 1960 , was exceeded with $C$. gigas after $1975(85000 \mathrm{t}$ ) (Table 4). At present, $C$. gigas also substitutes for the flat oyster Ostrea edulis, because of disease problems in that species (Grizel, 1983). French production of C. gigas has now reached $150000 \mathrm{t}$, with a value at first sale of nearly 1.3 billion francs, for market size oyster.

\section{Discussion}

Because the introduction in France of $C$. gigas was achieved in two stages, one unofficial the other official, it leaves open the question about the origin of the viruses which affected $C$. angulata. Three events occurred at approximately the same time, making it difficult to determine their exact order and to know their role and relative importance in the origin of the epizootic. These three events were: (a) the importation of $C$. angulata from Portugal, where gill disease had been described by Ferreira and Dias (1973); (b) the unofficial introduction of C. gigas from Japan; and (c) the progressive decline in the physiological condition of the French cultivated population of $C$. angulata (Héral et al., 1986). These observations lead to four hypotheses: (1) the origin of the disease could have been in Portugal and the transfers from Portugal to France could have spread the virus; (2) the iridoviruses were pathogenic exotic agents introduced with $C$. gigas, a safe carrier host; (3) the viruses were present in the $C$. angulata populations or in French waters, but the disease expressed itself only after a decline in condition of the stock; (4) some combination of the above three hypotheses.

Recent studies (Bougrier et al., 1986) of hybridization between $C$. gigas and $C$. angulata confirmed the presence of the iridovirus in the F1 $C$. angulata population cultivated in Morlaix Bay and in La Trinité River, where the culture of $C$. angulata and $C$. gigas had been very limited. This suggests that the hypothesis of a vertical transmission of the disease could be retained for the spawning adults of $C$. angulata coming from Portugal and favours the hypothesis of the origin of the virus in Portugal.

Even if the role of $C$. gigas in the origin of the epizootic in C. angulata is left uncertain, it is necessary to record that the importation of this species as a substitute which demonstrated resistance to the viral diseases of the Portuguese oyster and to the two protozoan diseases of the flat oyster (Grizel, 1985) permitted the maintenance and expansion of oyster culture on the French Atlantic coast.

Regarding the circumstances of this introduction, it is important to mention that zoosanitary precautions were taken by the use of numerous histological and cytological controls. Furthermore, the technique of immersing the spat and the collectors in fresh water reduced substantially the introduction of an associated flora and fauna. Indeed 15 years after the mass introduction, only a few species survive in very restricted areas. These are the barnacles, Balanus amphitrite and Balanus albicostatus, the actinoid Aiptasia pulchella, the mollusc Anomia chinensis, and the algae Undaria pinnatifida and Laminaria japonica. The invertebrate biomasses near the oyster grounds are very low and mostly less than those described by Thorp et al. (1987) in the English harbours.

Notwithstanding that the introduction of $C$. gigas in France continues to be a commercial success, it is important to underline that this kind of introduction can present considerable dangers, particularly from the zoosanitary point of view. It is essential when the situation is not dramatically urgent to take maximum precautions during the importation and especially to follow the ICES recommendations concerning the introduction of non-indigenous species.

\section{References}

Beattie. J. H., Chew, K. K., and Hershberger, W. K. 1980 Differential survival of selected strains of Pacific oysters (Crassostrea gigas) during summer mortality. Proc. Nat. Shellfish. Assoc., 70: 184-189.

Belcher, T., et Pomellec, S. 1988. Expansion de l'algue d'origine japonaise Sargassum muticum (Yendo) Sensholt, sur les côtes françaises de 1983 à 1987. Cah. Biol. Mar., 29: 221231

Bougrier, S., Raguenes, G., Bachère. E., Tiger, G., et Grizel H. 1986. Essai de réimplantation de Crassostrea angulata en France. Résistance au chambrage et comportement des hybrides $C$. angulata-C. gigas. ICES CM 1986/F: 38, 6 pp.

Cahour, A. 1979. Marteilia refringens and Crassostrea gigas. Mar. Fish. Rev., 41: 19-20.

Comps, M. 1969. Observations relatives à l'affection branchiale des huitres portugaises (Crassostrea angulata Lmk). Rev. Trav. Inst. Pêch. marit., 33: 151-160.

Comps, M. 1970a. La maladie des branchies chez les huîtres du genre Crassostrea, caractéristiques et évolution des altér- 
ations, processus de cicatrisation. Rev. Trav. Inst. Pêch. marit., 34: 23-44.

Comps, M. 1970b. Observations sur les causes d'une mortalité anormale des huîtres plates dans le bassin de Marennes. Rev. Trav. Inst. Pêch. marit., 34: 317-326.

Comps, M. 1972. Observations sur la résistance d'huîtres du genre Crassostrea au cours de la mortalité massive de 1970 1971 dans le bassin de Marennes-Oléron. ICES CM 1972/ K, $22 \mathrm{pp}$.

Comps, M. 1983. Recherches histologiques et cytologiques sur les infections intracellulaires des mollusques bivalves marins. Thèse Doct. Etat Sci. Nat., Montpellier, 128 pp.

Comps, M., Bonami, J. R., Vago, C., et Campillo, A. 1976. Une virose de l'huître portugaise (Crassostrea angulata Lmk). C.R. Acad. Sci. Paris, 282 D: 1991-1993.

Comps, M., et Duthoit, J. L. 1976. Infection virale associée à la maladie des branchies de l'huître portugaise Crassostrea angulata Lmk. C.R. Acad Sci. Paris, 283 D: 1595-1596.

Deltreil, J. P. 1973. Evolution et conséquences de la mortalité de $C$. angulata dans le bassin d'Arcachon et l'estuaire de la Gironde de 1971 à 1973. ICES CM/K: 14, 6 pp.

Farnham, W. F., Fletcher, R. L., and Irvine, L. M. 1973 Attached Sargassum found in Britain. Nature, 243 (5404): 231-232.

Ferreira, P. S., et Dias, A. 1973. Sur la répartition et l'évolution de l'altération des branchies de Crassostrea angulata dans le Tage, Le Sado et l'Algarve. ICES CM/K: 6, $19 \mathrm{pp}$.

Grizel, H. 1983. Impact de Marteilia refringens et de Bonamia ostrea sur l'ostréiculture bretonne. ICES CM, Gen. . 9; 30 pp.

Grizel, H. 1985. Etude des récentes épizooties de l'huître plate Ostrea edulis et de leur impact sur l'ostréiculture bretonne. Thèse Doct. Etat Sci., Montpellier, 145 pp.

Gruet, Y. 1976. Présence de l'algue japonaise Sargassum mut- icum Yendo (Fensholt) sur la côte française de Normandie. Bull. Soc. Sci. Nat. Ouest. Fr., 74: 101-104.

Gruet, Y., Héral, M., et Robert, J. M. 1976. Premières observations sur l'introduction de la faune associée au naissan d'huîtres portugaises $C$. gigas Th. importé sur la côte atlantique française. Cahiers de biologie marine, 17: 173-184.

Héral, M., Deslous-Paoli, J. M. et Prou, J. 1986. Dynamique des productions et des biomasses des huittres creuses cultivées (Crassostrea angulata et Crassostrea gigas) dans le bassin de Marennes-Oléron depuis un siècle. ICES CM 1986/F: 41, $21 \mathrm{pp}$.

Héral, M., Prou, J., et Deslous-Paoli, J. M. 1986. Influence des facteurs climatiques sur la production conchylicole du bassin de Marennes-Oléron. Haliotis, 15: 193-207.

His, E. 1977. Observations relatives à l'infestation de C. gigas par le copépode parasite Mytilicola orientalis Mori dans le bassin d'Arcachon. ICES CM 1977/K: 23 pp.

Kopp, J. 1976. Présence d’une phéophycée américaine, Sargassum muticum sur les côtes françaises de la Manche. ICES CM K: 34,6 pp.

Le Borgne, M., Gras, M. P., Comps, M., Carruesco, G., et Razet, D. 1973. Observations sur la reproduction des huîtres dans la Seudre (Bassin de Marennes-Oléron) en 1972. ICES CM 1983/K: 16, 5 pp.

Perez, R., Lee, J. Y., et Juge, C. 1981. Observations sur la biologie de l'algue japonaise Undaria pinnatifida (Harvey) Suringer introduite accidentellement dans l'étang de Thau Science et Pêche. Bull. Inst. Pêch. marit., 315: 1-12.

Percz, R., Kaas, R.. et Barbaroux, O. 1984. Culture expérimentale de Yalgue Undaria pinnatifida sur les côtes de France. Science et Pêche. Bull. Inst. Pêch. marit., 33; 3-15.

Thorp, C. H., Pyne, S., and West, S. A. 1987. Hydroïdes enzoensis Okuda, a fouling serpulidac new to British coastal waters. 5. Nat. Hist., 21: 863-877. 
